\title{
Research on the Influence of Technology Finance on Technology Innovation
}

\author{
Zhang $\mathrm{Pu}^{1}$, Qiu Tian ${ }^{1}$, and Zhang Jiangpeng ${ }^{1}$ \\ ${ }^{1}$ School of Economics and Management, Inner Mongolia university of Science and Technology, Baotou \\ Street 7, China \\ Puzhang@163.com,413865711@qq.com,14442746@qq.com
}

Keywords: panel model, three stage of technology innovation, technology finance investment

\begin{abstract}
This paper is mainly to solve the financial problems in technological innovation. Using the panal data with 29 China provinces (excluding Tibet and Xinjiang) from 2003 to 2013, the paper analyses the effects of technology on financial innovation, the data error is less than ordinary method. The technology innovation can be divided into three stages: technology innovation, technology transformation and industrialization of high technology, financial technology will be divided into two aspects: public finance and technology financial market technology. The results show that different stages and technological finance have different effects on technological innovation and functions. Finally,
\end{abstract} some policy suggestions are put forward.

\section{INTRODUCTION}

In recent year, relying on investment driven, resource driven economic model, China's economy has made remarkable achievements, but also brought a series of problems, such as high pollution, excess capacity and so on. As the fire Silicon Valley investors and thinker Peter Tell binary view of life -- the future of the human race, or unique and innovation , or what is not or to decline, if only the repetition and imitation, from 1 to $\mathrm{N}$, mankind will face a series of problems. China's economy is currently in 1toN decadent, to solve these problems country should to achieve breakthroughs from 0 to 1 , technological innovation is particularly important. And technology Innovation needs the support of capital, and the high risk of technology innovation high yield can give full play to the function of financial diversification risk with the integration of technology and finance (Lewis,2017) Technolgy social emerged the research on the influence of Finance on technology innovation started from the earliest time development and enterprise innovation play an important role(Camagni R,2017), He believes that the innovation of enterprises is closely related to financial capital. After this study, there are fewer articles on financial and technological innovation. Until the 90s of last century, the rise of Silicon Valley and the support of the financial system behind its rise make it possible Scholars at home and abroad begin to pay close attention to the relationship between finance and technology innovation (HUS Po-Susan,2014).

After defining the concept of technology finance, the domestic scholars studied the technology finance both at the micro and macro level. As a sample, the empirical results of econometric analysis show that policy and autonomy type capital plays a significant role in promoting technological innovation, (Kuratko,2017), especially the policy sexual financing has a strong positive effect on technological innovation (Kogan, 2017),. The panel data, combined with static and dynamic panel data model method, is analysed empirically .The effect of technology finance investment on technology innovation is shown in the short term
(Acharya V,2017),Technology financial investment has significant positive effect on technology innovation, but the long-term is not significant The financial system plays a support for independent innovation of small and medium-sized enterprises in the long term, but there are large differences in the effect of short-term support (Ehara K,2017;Klagge B.2017).The stochastic frontier distance function the model of regional technology innovation efficiency of China confirmed that there exist significant differences, such differences and regional financial intermediaries to technological innovation support strength and support is positively related to the efficiency of financial intermediary (Rampini A,2017). The credit scale is negatively study based on provincial panel data found that the role of financial support for technological innovation is a long-term accumulation the process (Forés, Beatriz 2016). The research on the construction of dynamic panel model indicates that the scale of financial development, financial development and financial efficiency (Edmans A,2016) The development of a positive output capability of technology innovation on the public finance of technology and its research influence on the innovation of technology found that the government investment in technology contribution elasticity coefficient is higher than other investment in technology (Brogaard J, 2016).Investment enterprises of the elements, and the middle and low level of output of scientific research with government investment in technology is higher than that of high level scientific research area(He, Lingyun,2017). In addition, the cultural background of social relations makes social capital become the important factors influencing the innovation of technology in china (Muldrew C,2016) Perspective of social capital research, it is verified that there is a positive correlation between social capital and regional technological innovation and enterprise innovation performance(Bolton R E. 2016).

\section{MANUSCRIPT PREPARATION}

The process of the development of technology innovation and the long and complex, different stages of 
enterprise development, financial support is different, most of the domestic scholars will affect the finance of technology innovation as a whole, the lack of each period of financial innovation effect of new technology on technology, this paper will be divided into technological innovation the new technology incubator, new technology research and development for new products, new products for the development of emerging industries in 3 stages, and analyzes the mechanism of financial capital is different in these 3 stages, specific analysis of financial capital in the 3 stage is how to influence the innovation of technology. Because of the different functions of technology finance in different stages of innovation, technology finance takes different ways of operation in different stages of innovation. Below, we divide the innovation of new products into 3 stages.

The first stage is the incubation stage of new technology or new products. At this stage, it is usually a new technology or product found by scientific research institutions, R \& D teams, universities and individuals. However, technological innovation is a large and complex systematic project, which mainly includes a series of processes of thought innovation, new technology or new product research and development. In this process requires a lot of money, and this process has a lot of uncertainty and risk, capital investment mainly to the enterprise's own funds, risk investment institutions to enterprises in the first round of financing. At the same time as the research and innovation of this phase has strong externalities, high risk, capital demand characteristics, it needs innovation, government funding to support this technology or products, for example, the government often to scientific research institutions and universities to provide funding to support their research and development of new technologies and new products. Or is the government to provide some technology company .Funds or tax free policies to support their technological innovation. At this stage, the number of patents to measure the incubation of new technologies or products is mainly the number of patents. From the above analysis, the influence of the number of patents is mainly the government investment in technology, the angel investment $V_{c}$ firm in the proportion is not large, the impact may be local, weak, specifically the case to see what area. Generally speaking, the government invests in funds, that is, the ratio of government investment in technology and the total expenditure of government finance, that is, the government branch technology cost ratio expression.

The second stage is the transformation stage of technological achievements. At this stage, the enterprise will transform new technology into new products, and put new products into the market. At the stage of new technology to new product, technology integration is needed. At this stage, the purchase and sale of technology contract is more active. The stage of new products being put on the market is important to be accepted by the market. Therefore, this stage reflects the achievements of technology indicators for the technology market turnover and new product revenue, with the relative numbers here, namely the technology market turnover and technology funding ratio and ratio of new product revenue and total industrial income said. At this stage, the externality of technological innovation gradually weakened, if the success of the transformation of technological achievements, technology enterprises such enterprises or investors will get huge profits, at the same time, this stage is also facing high risk and high return. Thus, the venture capital institution is the main body to provide financial services, and the innovation capital is the main part of venture capital at this stage. Public technology finance is the leading role at this stage.

The third stage is the gradual development of new products into emerging industries, that is, the industrialization stage of high-tech. At this stage, new products are produced on a large scale. During this period, new enterprises are constantly entering the market of new products, and the market of new products continues to expand, forming related high-tech industries. The innovation of technology to measure this stage index we use high-tech output to said that due to the direct investment in high-tech industry of our country foreign enterprises accounted for more than $50 \%$, so the impact of China's domestic financial technology innovation of technology of this phase is weak, the main business income in high tech industry the domestic enterprises as an alternative variable for this stage of technological innovation. The innovation of technology this stage has the demand for a variety of financial services technology, risk investment mechanism, PE mechanism plays a leading role; at the same time, this stage of the business may be the development of high-tech industry by raising capital market; because China is currently in the critical period of industrial structure adjustment, this stage the government may provide some financial guidance and the adjustment of the industrial structure, promote the development of high-tech industries.

\section{THE SELECTION OF FINANCIAL INDICATORS OF TECHNOLOGY}

\subsection{Selection of Financial Indicators of Science and Technology}

According to different investment entities, science and technology finance is divided into market science and technology finance and public technology finance. In the market, science and technology and finance, the above analysis shows that the capital market and venture capital are the main providers of science and technology financial services. In order to reflect the capital market on the innovation of science and technology support, the author adopts the technology of listed companies accounted for (LTCR) the relative numbers of technology financial services provided by capital markets, by reason of the relative number in the article: Science and technology listed company itself is the carrier of technological innovation, its technological finance also reflected the level of scientific and technological innovation, and the relative number can better reflect the capital market to support the strength of science and technology enterprises, is the embodiment of science and technology finance. Science and technology listed companies accounted for the number of science 
and technology listed companies / all the number of technology companies. According to Li Xiyi (2008), all of the Shanghai and Shenzhen Stock Exchange listed companies in the identification of 19 high-tech listed companies to obtain the number of defined standards, science and technology in each region in each year of listed companies. In addition, the theory of venture capital investment should be used to express with venture capital finance of science and technology, due to the availability of data, the number of venture capital institutions (VCI) to reflect the situation of risk investment.

The main body of public technology finance provides for the government, because in the early days of the innovation of technology research and development, most of external technological innovation, public welfare, strong in this stage, the government is the main investment subject, we use government investment in $\mathrm{R}$ \& D funds accounted for the proportion of fiscal expenditure to the government said that the government technology funding ratio (GSIR).

\subsection{Selection of Agent Variables for Regional Innovation}

By all the people, in different stages of innovation, technology and financial innovation on the conduction mechanism of the effect is different, so in the selection of the agent variables of regional innovation, we still choose different variables in different stages of innovation.

The first stage, the incubation stage of new technology, choose different provinces within a year the number of patents for regional innovation at this stage the proxy; the second stage, a stage of transformation of scientific and technological achievements, the main feature of this stage is the new technology and new products, the main measure is the technology market turnover ratio reflection and new products than income; the third stage, the stage of high-tech industry, high-tech industry is in the measure of domestic enterprise income.

Table 1: Technological innovation index

\begin{tabular}{|c|c|c|}
\hline Related variables & $\begin{array}{l}\text { evaluating } \\
\text { indicator }\end{array}$ & Proportion \\
\hline $\begin{array}{l}\text { Technological } \\
\text { innovation }\end{array}$ & $\begin{array}{c}\text { Patent } \\
\text { authorization } \\
\text { number }\end{array}$ & 0.48 \\
\hline $\begin{array}{c}\text { Transformation of } \\
\text { technological } \\
\text { achievements }\end{array}$ & $\begin{array}{c}\text { Technology market } \\
\text { turnover }\end{array}$ & 0.72 \\
\hline $\begin{array}{c}\text { Transformation of } \\
\text { technological } \\
\text { achievements }\end{array}$ & $\begin{array}{l}\text { New product input } \\
\text { ratio }\end{array}$ & 0.76 \\
\hline $\begin{array}{c}\text { Industrialization of } \\
\text { high and } \\
\text { new technology }\end{array}$ & $\begin{array}{l}\text { High tech industry } \\
\text { income of } \\
\text { domestic } \\
\text { enterprises }\end{array}$ & 0.5 \\
\hline \multicolumn{3}{|c|}{$\begin{array}{l}\text { According to the above theoretical basis, we can see } \\
\text { that in different stages of technology innovation, the } \\
\text { impact of technology Finance on technology innovation } \\
\text { is different, so the agent variable of technology } \\
\text { innovation in the model is divided into stages, and it } \\
\text { contains } 4 \text { variables. }\end{array}$} \\
\hline
\end{tabular}

\subsection{National panel model}

LNSIit $=\alpha i+\beta 1$ it LNGSIR it $+\beta 2$ it LNLTCit $+\beta 3$ it VCTit + uit, $i=1,2,3 \ldots 29$ (1.1)

Among them, SIit represents the panel data of proxy variables of technological innovation, which contains 4 indicators, namely SIit $=($ SI1it, SI2it, SI3it, SI4it). SI1it refers to the specific area of a year of patent authorization number; SI2it refers to the panel data technology market within a year of specific regional turnover accounted for the R \& D expenditure, namely the technology market turnover accounted for the ratio of the panel data; SI3it refers to the technology of new products business income accounted for the proportion of panel data the main business revenue; SI4it refers to the high-tech industry panel data of domestic enterprise income, the degree of industrialization of high-tech industry representatives. GISRit refers to the ratio of government investment in technology to the panel data, which represents the public finance part of technology finance. LTCRit refers to the high-tech listed companies accounted for the ratio of the panel data, on behalf of the capital markets to support the strength of technology companies; VCIit refers to the number of risk investment institutions, on behalf of the technology venture capital financial services provided by the two indicators on behalf of technology in the financial market financial part. The I in the national panel data model represents 29 provinces across the country, while the model is weakened the effect of heteroscedasticity on all indices is logarithmic LNSIit, LNGLSRit, LNLTCRit, but because of some provinces The number of venture capital institutions in some years is 0 , which cannot be taken into account Logarithm.

\subsection{The establishment of Panel Data Model}

Establishment of panel data model is usually based on mixed effect model and fixed model .Effect model and random effect model. The characteristic of the mixed regression model is that the regression coefficient is the same as that of any individual and cross section. In fixed effect model, Establishment of panel data model is usually based on mixed effect model and fixed model .Effect model and random effect model. The characteristic of the mixed regression model is that the regression coefficient is the same as that of any individual and cross section. In fixed effect model, $\alpha$ is a random variable, and its change is related to Xit. In the random effect model, the $\alpha$ is a random variable and its change .Nothing to do with Xit. The establishment of the model is determined by test. is a random variable, and its change is related to Xit. In the random effect model, the alpha I is a random variable and its change .Nothing to do with Xit. The establishment of the model is determined by test. Establishment of the model is determined by test.

\subsubsection{F Test}

Firstly, the model is tested by $\mathrm{F}$ test to determine whether it is a mixed effect model, and the test results are shown in table 2 . 
Table 2: F test

\begin{tabular}{cccc}
\hline $\begin{array}{c}\text { Agency variables } \\
\text { of regional } \\
\text { innovation }\end{array}$ & F statistics & P value & Test result \\
\hline $\begin{array}{c}\text { Patent } \\
\text { authorization } \\
\text { number }\end{array}$ & 45.28 & 0 & $\begin{array}{c}\text { Non } \\
\text { mixed } \\
\text { effect } \\
\text { model } \\
\text { Technology } \\
\text { market turnover }\end{array}$ \\
$\begin{array}{ccc}\text { Non } \\
\text { New product }\end{array}$ & 32.23 & 0 & $\begin{array}{c}\text { mixed } \\
\text { effect } \\
\text { input ratio }\end{array}$ \\
model \\
High tech
\end{tabular}

Table 2 shows the different panels of different technological innovation stage (i.e. the agent variables of different technological innovation model) in the middle panel of the third stages of high tech industrialization stage of the model is to accept the null hypothesis at the $5 \%$ significance level, that is to say the model for mixed effect model. Other models were rejected at the 5\% significance level, that is to say the panel data model for non-mixed effect model, next to the model Hausman test, determine the model belongs to the individual fixed effects model or random effects model.

\subsubsection{Hausman Test}

The difference between the individual fixation effect and the individual random effect is whether the intercept item is related to the explanatory variable. We use the Hausman test to determine the specific model type. The test results are shown in Table 3.

In Table 3, the type of model set according to the Hausman test has been given at the significant level of $10 \%$, and the corresponding panel data model has been set up according to the above results.

Table 3: Hausman test

\begin{tabular}{cccc}
\hline $\begin{array}{c}\text { Agency variables of } \\
\text { regional innovation }\end{array}$ & Statistic & $\begin{array}{c}\text { The } \\
\text { value of } \\
\mathrm{P}\end{array}$ & Test result \\
\hline $\begin{array}{c}\text { Patent authorization } \\
\text { number }\end{array}$ & 39.92 & 0.0003 & $\begin{array}{c}\text { Fixed effect } \\
\text { model }\end{array}$ \\
$\begin{array}{c}\text { Technology market } \\
\text { turnover }\end{array}$ & 8.24 & 0.0421 & $\begin{array}{c}\text { Random } \\
\text { effect model } \\
\text { New product input ratio }\end{array}$ \\
$\begin{array}{c}\text { High tech industry } \\
\text { income of domestic } \\
\text { enterprises }\end{array}$ & 14.28 & 0.0025 & $\begin{array}{c}\text { model } \\
\text { Fixed effect } \\
\text { model }\end{array}$ \\
\hline
\end{tabular}

\section{EMPIRICAL RESULTS AND ANALYSIS}

In this paper, the panel model is estimated according to the model setting type obtained by the above tests, and the regression results are shown in table 4 .

Table 4: Government investment ratio.

\begin{tabular}{ccccc}
\hline $\begin{array}{c}\text { Agency } \\
\text { variables of } \\
\text { regional } \\
\text { innovation }\end{array}$ & $\mathrm{R}^{2}$ & $\begin{array}{c}\text { Estimation } \\
\text { coefficient }\end{array}$ & $\begin{array}{c}\mathrm{T} \\
\text { statistics }\end{array}$ & $\mathrm{P}$ value \\
\hline $\begin{array}{c}\text { Patent } \\
\text { authorization } \\
\text { number }\end{array}$ & 0.93 & -0.05 & -0.49 & 0.62 \\
$\begin{array}{c}\text { Technology } \\
\text { market }\end{array}$ & 0.83 & 0.27 & 3.38 & 0.00 \\
$\begin{array}{c}\text { turnover } \\
\text { New } \\
\text { product }\end{array}$ & 0.79 & 0.10 & -1.28 & 0.2 \\
$\begin{array}{c}\text { input ratio } \\
\text { High tech } \\
\text { industry } \\
\text { income of } \\
\text { domestic } \\
\text { enterprises }\end{array}$ & 0.97 & 0.20 & 3.43 & 0.00 \\
\hline
\end{tabular}

Table 5: Proportion of listed companies of technology

\begin{tabular}{|c|c|c|c|c|}
\hline $\begin{array}{c}\text { Agency } \\
\text { variables of } \\
\text { regional } \\
\text { innovation }\end{array}$ & $\mathrm{R}^{2}$ & $\begin{array}{l}\text { Estimation } \\
\text { coefficient }\end{array}$ & $\begin{array}{c}\mathrm{T} \\
\text { statistics }\end{array}$ & $\begin{array}{c}\mathrm{P} \\
\text { value }\end{array}$ \\
\hline $\begin{array}{c}\text { Patent } \\
\text { authorization } \\
\text { number }\end{array}$ & 0.93 & -0.33 & -9.64 & 0.00 \\
\hline $\begin{array}{c}\text { Technology } \\
\text { market } \\
\text { turnover }\end{array}$ & 0.83 & 0.16 & 6.61 & 0.00 \\
\hline $\begin{array}{l}\text { New product } \\
\text { input ratio }\end{array}$ & 0.79 & -0.03 & -1.38 & 0.18 \\
\hline $\begin{array}{l}\text { High tech } \\
\text { industry } \\
\text { income of } \\
\text { domestic } \\
\text { enterprises }\end{array}$ & 0.97 & -0.02 & -0.11 & 0.91 \\
\hline
\end{tabular}

From the analysis of the panel model point of view, the first stage of stage of technology incubator, proxy technology innovation at this stage for the number of patents, can be seen at the significant level of $5 \%$ and $10 \%$, only the technology funds of government investment has a significant impact on the innovation of technology, and is negative, which may be due to research funding allocation of government structural problems, may also be due to government funding for technology innovation lag caused by.

The second stage, the transition stage of technological achievements, from the point of view of technology market turnover, the technology finance provided by each subject has a significant impact on technological innovation. The proportion of government investment in technology and the proportion of technology listed companies have a significant positive impact on the turnover of technology market, which is consistent with the theoretical basis. However, the number of venture capital institutions has a negative impact on the turnover of technology market, which may be due to the dominant role of VC institutions in venture 
capital at this stage. However, due to the characteristics of risk investment institutions in the rapid development of China's capital market in China is VC PE, and PE can fast screening mechanism mainly listed companies, so that the VC mechanism in risk investment institutions cannot play the role of the stage. From the aspect of the income ratio of new products, all kinds of technology financial services at this stage have no significant influence on technological innovation. The possible reason is that this stage is the intermediate link of technological innovation, and there are no strong externalities, so that the government funds in this stage of participation is low, so there is no significant impact. While the capital market and venture capital market degree is high, capital of the pursuit of high returns with low risk, and this risk is high, coupled with China's capital market and venture capital market is not perfect, the risk management ability is weak, which leads to the capital with the absence of the phenomenon at this stage, the market financial technology has no significant effect on the stage of technological. The third stage -- the stage of industrialization of high and new technology.

The third stage -- the stage of industrialization of high and new technology. In addition to the technology funds of government investment accounted for ratio of technological innovation has no significant effect, other variables have significant influence on the high-tech industry of domestic enterprises income, capital market and venture capital institutions number has a significant positive impact on it, which is consistent with the theory.

\section{CONCLUSIONS}

This paper is to research the influence of technology and finance to technological innovation, technological innovation will be divided into 3 stages, analyzes the nationwide mechanism and influence of technology and finance in the stage of technological innovation of each role in general, government investment in technology funds, high-tech listed companies accounted for and increases the risk of capital investment. The number of patents, technology market turnover, new product revenue and high-tech output value has positive effect, but the paper draws some opposite conclusion, and on this basis, further dividing the country into three regions, studied the effect of technology and finance in various regions on the innovation of technology, by studying the final conclusions because in each stage of technological innovation, mechanism of technology and finance is different, so the concrete analysis of technology and finance in each stage of technological innovation New influence. In the first, second stage, government investment in technology should be increased, and in the third stage, the most number of technological listed companies should be increased or the establishment and development of technology companies should be supported. Finally, according to the empirical results, in the second stage of technological innovation, most of the regional financial technology has no significant effect on the innovation of technology, the reason may be the two stage of financial service orientation is not clear due to the absence of service. Therefore, at this stage, technological innovation needs financial services between market oriented technology finance and public technology finance, such as policy finance.

This paper quantifies technology finance into government investment funds and technology listed companies, but there are many factors that influence technology finance. The quantification of technology finance is slightly insufficient. In the future, we should do further research on the technology finance, and make a more detailed description of the impact of each stage of the technological innovation.

\section{ACKNOWLEDGEMENTS}

This research was financial supported by The BaoTou Science and Technique Foundation (Number: 2015S2007-2-3); The Inner Mongolia social sciences planning project (Number: 2017ndb122), Innovation fund projects funded in Inner Mongolia university of science and technology (number: 2012ncl045);

\section{REFERENCES}

[1] Acharya V, Xu Z. Journal, 2017. Financial dependence and innovation: The case of public versus private firms, Financial Economics.124 (2): pp.223-243.

[2] Brogaard J, Denes M, Duchin R. 2016.Political Influence and Government Investment: Evidence from Contract-Level Data, Journal of political economy. pp.19-52.

[3] BASH Siddhartha, Glucose P J, 2014. Government policy towards entrepreneurial finance: Innovation investment funds, The Quarterly Review of Economics and Finance, (55): pp.2839

[4] Camagni R. Seminal Studies, 2017. Government policy and private investment in developing countries, Regional and Urban Economics.: pp.65-92.

[5] Ehara K. [R]. 2017. CIRJE, Faculty of Economics, University of Tokyo,

[6] Edmans, Alex, Mirko S. Heinle, and Chong Huang. 2016. The real costs of financial efficiency when some information is soft, Review of Finance 20.6: 2151-2182.

[7] Forés, Beatriz, and César Camisón,2016. Knowledge absorptive capacity: New insights for its conceptualization and measurement, Journal of Business Research 69(2) : pp.831-848 [8] HUS Po-Susan, TAN Xian, 2014. The complementary effect of internal learning capacity and absorptive capacity on performance: the mediating role of innovation capacity, Journal of Financial Economics, (112): pp.116-135.

[9] Kogan L, Papanikolaou D, Seru A, et al. 2017. Technological innovation, resource allocation, and growth, The Quarterly Journal of Economics, , 132(2): pp.665-712.

[10] Lewis Mark O.et al, 2017.Winners and losers: Creative destruction and the stock market, International Journal of Techno entrepreneurship 23(3):pp. 203-227. 